\title{
Evaluation of specific and non-specific immune response of four vaccines for caseous lymphadenitis in sheep challenged
}

Sohier M. Syame, Azza S. M. Abuelnaga, Eman S. Ibrahim and Ashraf S. Hakim

\author{
Department of Microbiology and Immunology, National Research Centre, Dokki, Cairo, Egypt. \\ Corresponding author: Sohier M. Syame, e-mail: sohiersyame@yahoo.com \\ Co-authors: ASMA: azzaabuelnaga@yahoo.com, ESI: dr.eman911@yahoo.com, ASH: migris410@yahoo.com \\ Received: 17-05-2018, Accepted: 31-07-2018, Published online: 17-09-2018
}

doi: 10.14202/vetworld.2018.1272-1276 How to cite this article: Syame SM, Abuelnaga ASM, Ibrahim ES, Hakim AS (2018) Evaluation of specific and non-specific immune response of four vaccines for caseous lymphadenitis in sheep challenged, Veterinary World, 11(9): 1272-1276.

\begin{abstract}
Background: Caseous lymphadenitis (CLA) is a serious disease affects sheep and goat, caused by Corynebacterium pseudotuberculosis. Due to it is non-treatable disease, so the effective preventive vaccines are considered a significant way to combat the disease. All strains of C. pseudotuberculosis have several virulence factors that associated with their cell invasion, survival, and proliferation such as phospholipase D (PLD), outer lipid coat, and secreted proteases.
\end{abstract}

Aim: The present study was directed to perform a comparative innate and acquired immune response assessment of different four vaccine formulas to evoke protection against induced (CLA) challenge in sheep.

Materials and Methods: Negative ELISA (free of CLA) 15 local breed male (Balady) sheep were divided into five groups, each has received a different vaccine while the control has received saline buffer. The first vaccine composed of toxoid PLD alone the second composed of toxoid PLD with bacterin (formalinkilled bacteria), the third vaccine composed of toxoid PLD plus covaccine 8 , while the fourth one composed of toxoid PLD plus locally produced polyvalent clostridial vaccine. The specific immune response was evaluated through lymphocyte proliferation assay using ELISA BrdU kit, while the nonspecific response was estimated by superoxide anion production and lysozyme activity assays.

Results: The study revealed that PLD toxoid could evoke the highest specific immune response, showing a stimulation index $(9.12 \%)$. On the other hand, combined toxoid PLD with bacterin followed by PLD toxoid showed a significant increase in the non-specific innate immune response.

Conclusion: The present study indicated that the toxoid PLD alone vaccine was most efficient and provided innate and acquired immune response in animals against CLA.

Keywords: Corynebacterium pseudotuberculosis, immune response, lymphocyte, phospholipase D, vaccine.

\section{Introduction}

Caseous lymphadenitis (CLA) is a chronic bacterial infectious disease of sheep and goats, caused by inhalation or ingestion of the Gram-positive bacterium Corynebacterium pseudotuberculosis, and is responsible for many economic losses $[1,2]$. Controlling CLA with antibiotics is unuseful since the bacteria have surrounded by a thick capsule, which can protect it inside the abscesses [3]. The disease presents in two different ways, the external, also known as superficial or cutaneous form which is characterized by the development of abscesses within the subcutaneous tissue or superficial lymph nodes. Pepin et al. [4] reported that at the first $24 \mathrm{~h}$ post-infection of lambs, microabscesses appear in the cortical region of the lymph node draining the site of inoculation with increasing of different cellular infiltration. Later, small nodules

Copyright: Syame, et al. Open Access. This article is distributed under the terms of the Creative Commons Attribution 4.0 International License (http://creativecommons.org/licenses/by/4.0/), which permits unrestricted use, distribution, and reproduction in any medium, provided you give appropriate credit to the original author(s) and the source, provide a link to the Creative Commons license, and indicate if changes were made. The Creative Commons Public Domain Dedication waiver (http://creativecommons.org/ publicdomain/zero/1.0/) applies to the data made available in this article, unless otherwise stated. of mineralization formed the classic "onion ring" sectioned presentation and regarded as virtually pathognomonic for CLA [5]. The second form of CLA is a visceral form which characterized by the formation of lesions in the host body, commonly the internal lymph nodes (primarily the mediastinal lymph nodes) or lungs also the kidneys, liver, or the mammary glands and less frequently infected the brain, heart, spinal cord, uterus, testes, and joints [6]. The pathogenesis of C. pseudotuberculosis is attributed to its virulence factors, the major one is an exotoxin called phospholipase D (PLD) that increasing vascular permeability and enhances dissemination of the bacteria by damaging endothelial cells. Another virulence factor is an outer lipid somatic coat that protects the bacteria from hydrolytic enzymes in host phagocytes where the bacteria replicate and release when rupture $[7,8]$.

As C. pseudotuberculosis can replicate within phagocytic cells, as a facultative intracellular pathogen, cellular immunity is believed to be necessary for efficient and effective protection. Not only lymphocytes are essential player in the specific immune response against the bacterium, but also macrophages have an essential role in the development of cellular either innate through secretion of bactericidal 
molecules and primary lysosomes or recognized acquired immunity [9].

In our investigation, we assessed the efficacy of cell-mediated innate and acquired immune response for different four vaccine formulas to trigger protection against CLA in sheep.

\section{Materials and Methods}

\section{Ethical approval}

The study was performed following the animal experimentation ethics.

\section{Animals and experimental design}

A total of 15 sheep, approximately 8-10 months old, were pretested as negative ELISA (free of CLA) and divided into five groups each group constituted three animals. Four groups were vaccinated by four different vaccine formulas, and the fifth group was kept as a non-vaccinated control group.

\section{Groups and vaccine formula}

\section{Group A (vaccine 1): Toxoid PLD}

Preparation of culture filtrate from isolated C. pseudotuberculosis biovar 1 (sheep origin), according to Brown et al. [10] with our modification as described by Syame [11] and Selim et al. [12]. $1 \mathrm{ml}$ of the filtrate was mixed with $1 \mathrm{ml}$ of oil adjuvant vaccine, as each formed dose $(2 \mathrm{ml})$ contained $23 \mu \mathrm{g}$ PLD.

\section{Group B (vaccine 2): Toxoid - bacterin}

It is composed of formalin-killed $C$. pseudotuberculosis whole cells [13] mixed with the toxoid PLD vaccine as 164 killed bacteria cells and $23 \mu \mathrm{g}$ $\mathrm{PLD} / 1 \mathrm{ml}$.

\section{Group C (vaccine 3): Toxoid PLD with covaccine 8}

Covaccine 8 is an imported vaccine formulated from a mixture of clostridial toxins, obtained from Schering plough animal health, the mixture contained $23 \mu \mathrm{g}$ PLD in $40 \mathrm{ml}$ of covaccine 8 [14].

\section{Group D (vaccine 4)}

Toxoid PLD vaccine combined with the polyvalent clostridial vaccine (Clostridium perfringens, C. tetani, C. septicum, C. chauvoei, and C. novyi) as $40 \mathrm{ml}$ of polyvalent clostridial vaccine mixed with $6 \mathrm{~g}$ lyophilized powder of formulated culture filtrate of PLD [11]. The polyvalent is a local vaccine prepared by Veterinary Serum and Vaccine Research Institute, Abbasia.

\section{Group E (control)}

Non vaccinated animals.

\section{Vaccination and experimental challenge}

Groups $1,2,3$, and 4 were vaccinated with the previously mentioned vaccine formula by $\mathrm{S} / \mathrm{C}$ inoculation of $2 \mathrm{ml}$ dose of vaccine in the middle third of the neck. All the vaccinated animals were revaccinated after 3 weeks of the first vaccination. After 3 weeks of the last vaccination, all five groups including the control non-vaccinated sheep were challenged with virulent biovar 1 sheep origin isolate with $2 \mathrm{ml}$ suspension containing $4 \times 10^{6} \mathrm{CFU}$ intradermally as $1 \mathrm{ml}$ in both sides of the neck. The non-specific cellular immune response represented by stimulated macrophages was measured at 2 weeks after the challenge while the specific excited lymphocytes response was assessed at 4 weeks.

\section{Collection of antiserum}

Blood samples were obtained from the jugular vein and drawn through a syringe without anticoagulant 2 weeks after the challenge, kept in slanting position for about $2 \mathrm{~h}$, and after that centrifuged at $1600 \times \mathrm{g}$ for $25 \mathrm{~min}$ at $4^{\circ} \mathrm{C}$. The supernatant was collected in sterile vials, and the serum was kept at $57^{\circ} \mathrm{C}$ in a water bath for $30 \mathrm{~min}$ to inactivate the complement system, then stored at $-20^{\circ} \mathrm{C}$ for testing.

\section{Superoxide anion production assay}

The assay was performed in triplicate at a sterile tissue culture plate; a working solution was prepared (cytochrome-C purchased from Sigma $200 \mathrm{mg} / 1 \mathrm{ml}$ Hanks balanced salt solution (HBSS) and prewarmed to $37^{\circ} \mathrm{C}$. Each well received a mixture of $100 \mu 1$ of working solution and $50 \mu \mathrm{l}$ of the sera with different vaccine formula in HBSS; the control wells received the working solution only. The superoxide dismutase (4 units/well) was added to the mixture and served as a blank reference well. The plate was incubated at $37^{\circ} \mathrm{C}$ in a humidified $5 \% \mathrm{CO}_{2}$ tension for $2 \mathrm{~h}$, then read at $570 \mathrm{~nm}$ using ELISA reader [15]. More superoxide anion production, more reduction of cytochrome $\mathrm{C}$ red color and was calculated by linear regression analysis. Purified superoxide dismutase was used to confirm the specificity of superoxide production.

\section{Lysozyme activity assay}

Tested sera $(100 \mu \mathrm{l})$ were added to $2 \mathrm{ml}$ of a suspension of Micrococcus lysodeikticus ATCC 4698 Sigma $(0.2 \mathrm{mg} / \mathrm{ml})$ in a $0.05 \mathrm{M}$ sodium phosphate buffer ( $\mathrm{pH}$ 6.2). The reactions were carried out at a $20^{\circ} \mathrm{C}$, and optical density at $530 \mathrm{~nm}$ was measured between $5 \mathrm{~min}$ and $20 \mathrm{~min}$ on a spectrophotometer. A lysozyme activity unit was defined as the amount of enzyme producing a decrease in optical density of $0.001 / \mathrm{min}$ against standard curves [16,17].

\section{Preparation of peripheral blood mononuclear cells (PBMCs)}

Five $\mathrm{mm}$ of the jugular vein blood sample were obtained from each animal through heparinized Vacutainer $(10 \mathrm{IU} / \mathrm{ml})$. Heparinized blood was diluted 1:1 with sterile phosphate buffered saline (PBS) and overlaid on the Ficoll separation medium by $3: 1$ in $20 \mathrm{ml}$ test tubes, then centrifuged the tubes at $800 \mathrm{rpm}$ for $10 \mathrm{~min}$ at $4^{\circ} \mathrm{C}$. The PBMCs in the interface layer represented both lymphocytes and monocytes were harvested and immediately washed 2 times with sterile PBS, then centrifuged at $1500 \mathrm{rpm}$ for $10 \mathrm{~min}$ at room temperature. After washing, PBMCs were resuspended in $2 \mathrm{ml}$ RPMI 1640 medium [18]. 
Evaluation of specific cellular immune response by the lymphocyte proliferation assay (LPA) [19].

LPA measures the ability of lymphocyte to undergo a clonal proliferation when stimulated by foreign antigen. The amount of proliferation is detected using cell proliferation ELISA BrdU (Bromodeoxyuridine) colorimetric kit (Roche) as a thymidine analog incorporated into DNA replication and can be detected immunocytochemically after partial denaturation of double-strand DNA by a specific anti-BrdU monoclonal antibody. $10 \mu 1$ of the reconstituted cells were then mixed with $90 \mu 1$ of $0.4 \%$ trypan blue stain and hemocytometer checked. The number of lymphocytes/ml of each sample was calculated:

$$
=\frac{\text { Number of lymphocyte counted }}{\text { Number of triple ruled square }}
$$

$100 \mu 1$ of $5 \times 10^{5}$ viable lymphocytes cells $/ \mathrm{ml}$ were dispensed in tissue culture plate wells, the plate was pulsed with the kit reagents followed the instructions and the plate was incubated at room temperature until a sufficient color was developed. The absorbance of the samples was measured in ELISA reader at $370 \mathrm{~nm}$.

\section{Statistical analysis}

Statistical analysis was doneusing model GLM of SAS software version (6.12) [20].

The superoxide anion production was calculated as follows:

Blank well - test well $\times 15.87^{*}$

As 15.87 is a coefficient calculation based on the quantity of solution per well and dimension of the well.

The stimulation index (SI) was calculated as follows:

$$
\text { S.I }=\frac{\text { Mean O.D sample }}{\text { Mean O.D control }}
$$

$>1$ indicates a positive proliferation response.

\section{Results and Discussion}

The present investigation was directed to evaluate both the non-specific and specific cellular efficacy of toxoid PLD (toxoid of C. pseudotuberculosis) as a single vaccine compared to other used combined vaccine formula to evoke protection against
C. pseudotuberculosis virulent strain locally isolated from sheep suffered from CLA in Egypt. Once the organism is intracellular, the antitoxins antibodies probably have a little impact on the recovery from infection so that the cellular dependent responses may be essential in eliminating the organism [21].

During the early stages of the disease, macrophage infiltration was directed to combat and the organism, by oxidative expressed in the production of bactericidal oxygen free radicals and non-oxidative mechanism (enhancement of lysozymes activity). Lysozyme is a mucolytic enzyme able to induce damage of peptidoglycan, so it is highly effective, especially against Gram-positive bacteria [22,23].

The achieved data in Table- 1 exhibited a significant increase in the level of superoxide anion production of simulated macrophage vaccinated groups, compared with the control one. The highest increased in Group B (toxoid PLD+bacterin) little followed by Group A (Toxoid PLD alone), then Groups D and C nearly similar response. Furthermore, near results obtained in Table-2 showed that the significant lysozyme activity of simulated macrophage was the highest increased in Group B followed by Group A, then $\mathrm{C}$ and the least one was represented in Group D. These outcomes were consistent with those of other studies [24,25] and may be attributed to the presence of somatic proteins associated with bacterin which induce the production of IFN- $\gamma$, a very important cytokine related to innate immune response and macrophage stimulation [26].

From the other sides, the acquired immune response which may result after vaccination was evaluated by the LPA using ELISA BrdU colorimetric kit. The data in Table-3 showed a marked significant positive lymphocyte proliferation response in vaccinated groups, pointed to the highest ( $\mathrm{SI}=9.12)$ represented by Group A (toxoid PLD) followed by other groups by far great extent. The results indicated that PLD stimulated the specific cellular immune response and highly suggested to confer the organism and this concern was agreed with other data [27,28].

\section{Conclusion}

Drawing from the obtained data of this work, the most efficient protection against CLA was provided in animals vaccinated with toxoid PLD alone.

Table-1: Effect of the four vaccine formula on superoxide anion liberation from triggered macrophages in tested sheep sera after 2 weeks from the challenge.

\begin{tabular}{lccc}
\hline Type of vaccine & Mean OD & Mean OD & Superoxide anion (ng/mI) \\
\hline Toxoid PLD (Group A) & $0.192 \pm 0.02$ & Blank & 3.61 \\
Toxoid PLD+Bacterin (Group B) & $0.186 \pm 0.01$ & $0.420 \pm 0.04$ & 3.71 \\
Toxoid PLD+Covaccine 8 (Group C) & $0.252 \pm 0.04$ & & 2.67 \\
Toxoid PLD+polyvalent clostridial & $0.257 \pm 0.04$ & & 2.6 \\
vaccine (Group D) & $0.308 \pm 0.06$ & & 1.77 \\
Control group (Group E) & & \\
\hline
\end{tabular}

Data are presented as mean \pm SE. $P<0.05$. SE=Standard error, PLD=Phospholipase D

Veterinary World, EISSN: 2231-0916 
Table-2: Effect of the four vaccine formula on lysozyme activity of stimulated macrophages in tested sheep sera after 2 weeks from the challenge.

\begin{tabular}{lcc}
\hline Type of vaccine & Mean OD & Lysozyme activity \\
\hline Group A & $1.552 \pm 0.02$ & 100 units \\
Group B & $1.379 \pm 0.01$ & 177 units \\
Group C & $2.378 \pm 0.04$ & 78 units \\
Group D & $2.069 \pm 0.02$ & 48 units \\
Group E & $2.556 \pm 0.04$ & 0 unit \\
\hline
\end{tabular}

Data are presented as mean \pm SE. $p<0.05 . S E=$ Standard error

Table-3: Mean OD value of lymphocyte proliferation response after 4 weeks from a challenge.

\begin{tabular}{lcc}
\hline Type of vaccine & Mean OD & Lysozyme activity \\
\hline Group A & $0.575 \pm 0.03$ & 9.12 \\
Group B & $0.305 \pm 0.02$ & 4.8 \\
Group C & $0.361 \pm 0.02$ & 5.73 \\
Group D & $0.290 \pm 0.01$ & 4.6 \\
Group E & $0.063 \pm 0.002$ & 1 \\
\hline
\end{tabular}

Data are presented as mean \pm SE. $p<0.05 . S E=$ Standard error

The mentioned vaccineevoked the highest stimulation index, which expressed specific lymphocyte proliferation response by a big margin with the other used combined vaccines. In the same direction, it was able to induce the innate immune response as a macrophage stimulation mechanism in a long approximate border.

\section{Authors' Contributions}

SMS supervised the experiment. ASMA and ESI shared in experimental steps, vaccination, challenge and collection of samples. ASH conducted the immunological assays. SMS and ASH prepared and reviewed the manuscript. All authors read and approved the final manuscript.

\section{Acknowledgments}

The authors acknowledge Desert Research Center for Animal Provision and the investigation was supported by grant number 2134 from Technology Development and Scientific Sector Science and Technology Center, Academy of Scientific Research and Technology, Egypt.

\section{Competing Interests} interests.

The authors declare that they have no competing

\section{References}

1. Jesse, F.F.A., Bitrus, A.A., Abba, Y., Chung, E.L.T., Sadiq, M.A., Hambali, I.U., Perera, H., Haron, A.W., Lila, M.A.M., Saharee, A.A., Norsidin, M.J. and Harith, A. (2016) Strategic management of a clinical case of recurrent caseous lymphadenitis in a goat farm. Res. J. Vet. Pract., 4(3): 42-46.

2. Nassar, A.F., Gabriela, T.D., Regina R., Simone M., Eloísa M. S., Juraci N. and Lilian G. (2015) Diagnostic comparison of Corynebacterium pseudotuberculosis through microbiological culture and PCR in sheep samples. Arq. Inst. Biol., 82: 1-6.
3. Colom-Cadena, A., Velarde, R., Salinas, J., Borge C., Garcia-Bocanegra, I., Serrano, E., Glasso, D., Bach, E. and Casas-Diaz, E. (2014) Management of a caseous lymphadenitis outbreak in a new Iberian ibex (Capra pyrenaica) stock reservoir. Acta Vet. Scand., 56: 83-94.

4. Pepin, M., Fontaine, J.J., Pardon, P., Marly, J. and Parodi, A.L. (1991) Histopathology of the early phase during experimental Corynebacterium pseudotuberculosis infection in lambs. Vet. Microbiol., 29: 123-134.

5. Pepin, M., Pittet, J.C., Olivier, M. and Gohin, I., (1994b) Cellular composition of Corynebacterium pseudotuberculosis pyogranulomas in sheep. J. Leukoc. Biol., 56: 666-670.

6. Dar, L.M., Hussain, S.A., Rashid, A., Parihar, S., Abdullah, S. and Rather, F. A. (2013) Caseous lymphadenitis in a sheep-postmortem and histopathological findings. Int. J. Livestock Res., 3(3): 69-73.

7. Flores-Díaz, M., Monturiol-Gross, L., Naylor, C., Alape-Girón, A. and Antje, F. (2016) Bacterial sphingomyelinases and phospholipases as virulence factors. Microbiol. Mol. Biol. Rev., 80(3): 597-628.

8. Santos, E.M.S., Santos, H.O., Cangussu, A.R. Costa, K.S. and Dias, I. (2016) Antigens of Corynebacterium pseudotuberculosis with promising potential for caseous lymphadenitis vaccine development. Cad. Ciênc. Agrá., 8(2): 90-99.

9. Bastos, B.L., Dias Portela, R.W., Dorella, F.A., Ribeiro, D. and Seyffert, N. (2012) Corynebacterium pseudotuberculosis: Immunological responses in animal models and zoonotic potential. J. Clin. Cell. Immunol., S4: 5.

10. Brown, C.C., Olander, H.J., Biberstein, E.L. and Morse, S.M. (1986) Use of a toxoid vaccine to protect goats against intradermal challenge exposure to Corynebacterium pseudotuberculosis. Am. J. Vet. Res., 47: 1116-1119.

11. Syame, S.M. (2006) Characterization of Secretory Proteins that Secreted from Corynebacterium pseudotuberculosis. Ph.D. Thesis., Bacteriology, Fac. Vet. Med., Cairo Univ, Giza, Egypt.

12. Selim, S.A., Syame, S. M., Ebessy, E. A. Effat, M.M., Hakim, A.S. and Balata, M.A. (2016) Evaluation of protective efficacy of mixed PLD toxoid and clostridial vaccines against caseous lymphadenitis (CLA) in small ruminants at Egypt. Int. J. Microbiol. Res., 7(3): 102-113.

13. Moussa, I.M., Mohamed, S.A., Hessain, A.M., Kabli, S.A., Hemeg, H.A. and Selim, S.A. (2016) Vaccination against Corynebacterium pseudotuberculosis infections controlling caseous lymphadenitis (CLA) and oedematous skin disease. Saudi. J. Biol. Sci., 23(6): 718-723.

14. Eggleton, D.G., Doidge, C.V. Middleton, H.D. and Minty, D.W. (1991) Immunisation against ovine caseous lymphadenitis: Efficacy of component Corynebacterium pseudotuberculosis toxoid vaccine and combined clostridial-coryne bacterial vaccines. Aust. Vet. J., 68: 320-321.

15. Masoud, R., Bizouarn, T., Trepout, S., Wien, F., Baciou, L. and Marco, S. (2015) Titanium dioxide nanoparticles increase superoxide anion production by acting on NADPH oxidase. PLoS One, 10(12): 1-17.

16. Jiang, Z.L. and Huang, G.X. (2007) Resonance scattering spectra of Micrococcus lysodeikticus and its application to assay of lysozyme activity. Clin. Chim. Acta, 376: 136-141.

17. Helal, R. and Melzig M.F. (2008) Determination of lysozyme activity by a fluorescence technique in comparison with the classical turbidity assay. Pharmazie, 63: 415-419.

18. Hogan, J.S., Smith, K.L., Weiss, W.P., Todhunter, D.A. and Schockey, W.L. (1990) Relationships among Vitamin E, selenium, and bovine blood neutrophils. J. Dairy. Sci., 73(9): 2372-2378.

19. Perros, P. and Weightman, D.R. (1991) Measurement of cell proliferation by enzyme-linked immunosorbent assay (ELISA) using a monoclonal antibody to bromodeoxyuridine. Cell Prolif., 24: 517-523.

20. SAS. (2000) Step-by-Step Programming with Base SAS Software. SAS Institute Inc, Cary NC.

21. Ribeiro, D., Dorella, F.A., Pacheco, L.G.C., Thiago, L.C., 
Portela, R.W.D., Meyer, R., Miyoshi, A., Luvizotto, M.C.R. and Vasco, A. (2013) Subclinical diagnosis of caseous lymphadenitis based on ELISA in sheep from Brazil. $J$. Bacteriol. Parasitol., 4(3): 1-4.

22. Vance, R.E. (2010) Inflammasome activation: How macrophages watch what they eat. Cell Host Microb., 21: 3-5.

23. McKean, S., Davies, J. and Moore, R. (2005) Identification of macrophage-induced genes of Corynebacterium pseudotuberculosis by differential fluorescence induction. Microb. Infect., 7: 1352-1363.

24. Moura-Costa, L.F., Bahia, R.C., Carminati, R., Vale, V.L., Paule, B.J., Portela, R.W., Freire, S.M., Nascimento, I., Schaer, R., Barreto, L.M. and Meyer, R. (2008) Evaluation of the humoral and cellular immune response to different antigens of Corynebacterium pseudotuberculosis in Canindé goats and their potential protection against caseous lymphadenitis. Vet. Immunol. Immunopathol., 15: 131-41.
25. Vera, L., Costa, V., Marcos, C. S., Andréia, P. S., Soraya, C. T., Lília, F. de Moura, C. (2016) Humoral and cellular immune responses in mice against secreted and somatic antigens from a Corynebacterium pseudotuberculo sis attenuated strain: Immune response against a C. pseudotuberculosis strain. BMC Vet. Res., 12(1): 195.

26. Kitanaka, S. (2016) Chemical compounds in natural medicines that affect macrophages and adipocyte cells. Yakugaku Zasshi, 136(9): 1195-216.

27. El-Enbaawy, M.I., Saad, M.M. and Selim, S.A. (2005) Humoral and cellular immune responses of a murine model against Corynebacterium pseudotuberculosis antigens. Egypt J. Immunol., 12: 13-19.

28. Dorella, F.A., Pacheco, L.G., Seyffert, N., Portela, R.W., Meyer, R., Miyoshi, A. and Azevedo, V. (2009) Antigens of Corynebacterium pseudotuberculosis and prospects for vaccine development. Expert Rev. Vaccine, 8(2): 205-213.

$* * * * * * * *$ 